\title{
PARTICIPATIVE MANAGEMENT IN HEALTH CARE SERVICES
}

\author{
M Muller
}

\begin{abstract}
THIS ARTICLE IS BASED ON A PAPER DELIVERED AT A
NATIONAL CONFERENCE ON THE 30th SEPTEMBER

1993, TITLED: RE-ENGINEERING FOR COST-EFFECTIVE HOSPITAL MANAGEMENT TO ENHANCE PROCESS EFFICIENCY AND PATIENT CARE, WITH HOSPITAL MANAGERS AS THE MAIN TARGET GROUP.
\end{abstract}

\section{UITTREKSEL}

Die behoefte aan en eise wir hoë gehaltebestuur van alle aktiviteite rakende gesondheidsdienslewering, vereis 'n deelnemende bestuursbenadering. Die doel met hierdie artikel is om die proses van deelnemende bestuur te verken. om " $n$ model vir deelnemende bestuur te gentereer en te beskryf, met die fokus op die prosedure van deelnemende bestuur, en om laastens enkele riglyne vir die operasionalisering yan die model te formuleer. ' Verkennende, beskrywende en teoriegenererende navorsingsontwerp is nagevolg. $\mathrm{Na}$ 'n literatuuroorsig is duar van ' $n$ induktiewe denkstrategie gebruik gemaak om die sentrale konsepte te identifiseer en te definieer, gevolg deur die formulering van a paar toepaslike stellings en riglyne.

Deelnemende bestuur word beskryf as 'n proses wat uit die volgende deelnemende bestuurshandelinge bestaan. naamlik interakttewe besluitneming en probleemoplossing. gedeelde bestuurselfstandigheid, bemagtiging, organisatoriese transformering of omvorming, met dinamiese kommunikusie binne die gesondheidsdiens. Die wetenskaplike metode van beraming, beplanning, implementering en evaluering vorm' $n$ integrale deel van die deelnemende bestuursproses.

'n Kontinuum van interaktiewe besluitneming en probleemoplossing word beskryf, die verskillende rolspelers wat betrokke is, asook die vlakke van interaktiewe besluitneming en probleemoplossing. Die mees toepaslike besluitnemingstrategie behoort vir proaktiewe en reaktiewe besluimeming benut te word.

Toepaslike beginsels en aunnames in elke declnemende bestuurshandeling word beskryf. Daar word aanbeveel dat hierdie voorgestelde model vir suiwering aan ' $n$ literatuurkontrole en intersubjektiewe dialoogvoering met kundiges onderwerp word, asook ' $n$ modelgevalbeskrywing van deelnemende bestuur, ten einde vertrouenswaardigheid van die navorsing te verseker.

\section{ABSTRACT}

The need and demand for the highest-quality management of all health care detivery activities requires a participative management approach. The purpose with this article ts to explore the process of participative management, to generate and describe a model for such management. focusing mainly on the process of participative management, and to formulate guidelines for operationalisation of the procedure. An exploratory, descriptive and theory-generating research design is pursued. After a brief literature review, inductive reasoning is mainly employed to identify and define central concepts. followed by the formulation of a few applicable statements and guidelines.

Participative management is viewed as a process of that constitutes the elements of dynamic interactive decision-making and problem-solving, shared governance. empowerment, organisational transformation, and dynamic communication within the health care organisation. The scientific method of assessment, planning, implementation and evaluation is utilised throughout the process of participative management.

A continumm of interactive decision-making and problem-solving is described, the different role-players involved, as well as the levels of interactive decision-making and problem-solving. The most appropriate decision-making strategy should be employed in pro-active and reactive decision-making.

Applicable principles and assumptions in each element of participative management is described. It is recommended that this proposed model for participative management be refined by means of a literature control, interactive dialogue with experts and a model case description or participative management, to ensure the trustworthiness of this research.

\section{INTROIDUCTION}

The health care managers of today are facing greater challenges than ever before. One only has to consider the necessity for them to keep pace with the needs, demands, desires and expectations of health care consumers, health care providers and health care insurers/funders, all of whom are role-players (claimants) in health care. These needs, demands, desires and expectations are influenced by various external factors, and the most significant of these are the present conomic status of the country with consequent financial constraints, the dynamics of the socio-political changes and the inedico-technological advances.
A desire most commonly expressed by the role-players in health care delivery, is that of involvement - involvement, not only in the daily practice-related activities but, also in those management activities and decisions that will facilitate quality patient care and quality work life for the various employees. 
The need and demand for the highest-quality management of all health care delivery activities are intensifying to such a degree that survival has become an issue of greatest concern for some of the health care organisations of today. Hence, total quality management is of paramount importance for ensured efficiency. It requires a participative management approach that would accommodate the needs, desires and expectations of the health care providers, health care consumers and insurers/funders as well as those of managers who are, after all, accountable for the management outputs of the health care organisation.

The purpose of this research is to explore the process of participative management, to generate and describe a model for such management in health care organisations, and to formulate guidelines for operationalisation of the model.

An exploratory, descriptive and theory-generating research design is pursued. After a brief literature review, inductive reasoning is mainly employed to identify and define central concepts, followed by the formulation of a few applicable statements. A tentative model (focusing at this stage mainly on the process) for participative management in a health care organisation is described and hence, no refinement measures have been considered as yet.

\section{LITERATURE REVIEW}

Schulz \& Johnson (1990:287) describe participative management as a philosophy of management in which hospital employees and health care professionals participate in a meaningful way in the administration of the hospital. Managers do not abdicate their responsibilities, but share it. In doing so, the managers can actually gain more control over their responsibilities. This view is confirmed by Swansburg (1993:248-250), in that, when top management implements a philosophy of decentralised decision-making, the stage is set for involving people in making decisions at the level where the action occurs. Authority is delegated from top managers downward to the people who deliver the health care. Subsequently, objectives or duties are assigned, authority granted, and an obligation or responsibility created by acceptance, thus the employee is also accountable for the results. This management approach prevents a communication bottle-neck inasmuch that the people closest to the problem solve it. This results in efficient and cost-effective management.

According to Swansburg (1993-250), the components of participatory management are trust, informed commitment, goals and objectives, and autonomy. The employee is trusted to make decisions, facilitated by adequate teaching and enablement. Managers who empower and facilitate employee performance, communicate trust.
Deliberate and meaningful involvement in decision-making requires commitment from all participants. This commitment is gained from seeing managers at the level of patient care and knowing that the purpose of the organisation is patient care. Managers are working with employees and professionals to produce that quality patient care. Therefore, under participative management, commitment is elicited, not imposed.

A climate of openness should be introduced to facilitate problem-solving by joint planning, consultation, consensus and negotiation. Participative management encourages a healthy working environment and also allows for optimal use of employees' abilities without relinquishing the ultimate authority and responsibility of management.

Goal-selting activities should occur in a participatory manner. The process is reciprocal with the manager and employee together developing goals and objectives that are challenging, clear, consistent and specific. The manager and employee both will be motivated and any conflict reduced. Autonomy, on the other hand, is the state of being independent, of having responsibility and the right to make decisions.

Stander (1992:68-69) defines participative management as a dynamic process of mutual decision-making and creative problem-solving through active participation of the employees, with the distribution of authority and shared accountability.

Employees want to be treated as equal partners and colleagues in the health care delivery system. Therefore, participation in management should be inclusive rather than exclusive, although voluntary. The climate of the organisation, as set by the philosophy of its managers, will motivate the participants at a level consistent with their goals and desires. Participation is also increased by facilitators who are enthusiastic and expert. It is evident that participative management requires restructuring of the health care organisation to enable decision-making and problem-solving. and shared governance at the lowest possible level. Decentralisation sets the degree to which authority is discharged, downward within the organisation, to its divisions, services and units. It encompasses the delegation of decision-making authority and power, responsibility and shared accountability, also known as shared governance in the health care delivery system (Swansburg. 1990: 247).

Participative management involves interactive assessment, planning, implementation and evaluation by the appropriate participants in the health care organisation. This should enourrage collaborative, shared govemance and ownership by all role-players in the health care delivery system. Different decision-making strategies could be employed to foster participation which requires specific education and enablement (better known as empowerment) of all the roleplayers to be involved in participative management.

Empowerment is seen as a social process of recognising, promoting and enhancing people's abilities to meet their own needs, solve their own problems and mobilise the necessary resources in order for them to feel in control of their own lives. It helps people to assert control over the factors which affect their health, work and life (Gibson, 1991:359). Empowerment is the interpersonal process of providing the proper tools, resources and environment to build, develop and increase the ability and effectiveness of others, for them to set and reach goals for individual and social ends. Empowerment occurs between two or more people - the person who empowers and the person being empowered both benefit from the process.

Participative management necessitates a total organisational paradigm shift. This poses a difficult leadership challenge. Hence, the implementation of a model of participative management should not only effect personal. professional and organisational growth, but provide positive results with regard to the quality of health care rendered, the work life experienced by the different role-players, and also improve organisational outputs. A new dynamic organisational structure is established, making allowance for some degree of creativity.

From the analysis of different models described in the literature, it was noted with great interest the number of liaison committees, joint professional responsibility committees, quality circles and practice development groups that have evolved, with the focus on qualitative analysis of a particular organisation based on the needs, desires and expectations of the role-players.

\section{A MODEL FOR PARTICIPATIVE MANAGEMENT IN A HEALTH CARE ORGANISATION}

A model for participative management applicable for any health care organisation is proposed. The fundamental dynamics and assumptions are highlighted, and the structure and process of participative management described in which four participative management actions are suggested. Dynamic communication is seen as an encompassing and integrating function as well as an obligation in order to facilitate successful participative management.

\section{UNDERLYING DYNAMICS ANI) ASSUMPTIONS}

Justification for participative management is based on the following assumptions:

- role-players in the health care delivery system display an informed service commitment towards health care delivery; 
- professional health care providers are independent practitioners who utilise critical analytical reasoning skills in their clinical practice.

- role-players in the health care delivery system have potential for continuous personal and professional growth;

- motivation of the role-players in the health care delivery system is augmented by their individual involvement in decision-making and problem-solving;

- role-players in the health care delivery system will support organisational goals when these goals meet their needs, desires and expectations, therefore congruency between individual and organisational goals is displayed;

- participative management facilitates imaginative, creative decision-making and problem-solving, improves productivity and quality work life experienced by employees;

- participative management fosters shared responsibility, accountability and ownership ("shared governance") in the health care delivery system;

- shared ownership, responsibility and accountability reduces resistance 10 change;

- the four participative management actions are interrelated and interdependent.

\section{THE STRUCTURE AND PROCESS OF PARTICIPATIVE MANAGEMENT}

The objective of participative management in a health care delivery system is the promotion/ improvement, maintenance and restoration of quality health care service, financial efficiency and quality personnel services to the employees

Participative management is viewed as a process that constitutes the elements of dynamic interactive decision-making and problem-solving, shared ownership and accountability of all role-players in the health care delivery system - referred to as shared governance - organisational transformation, enablement or empowerment of role-players and dynamic communication within the health care organisation (refer to Figure 1).

The scientific method of assessment, planning, implementation and evaluation is utilised throughout the process of participative management. The four participative management actions are described separately.

\section{a) Interactive decision-making and problem-solving}

Interactive decision-making and problem-solving infers dynamic and purposeful joint participation in such activities

\section{Communication}

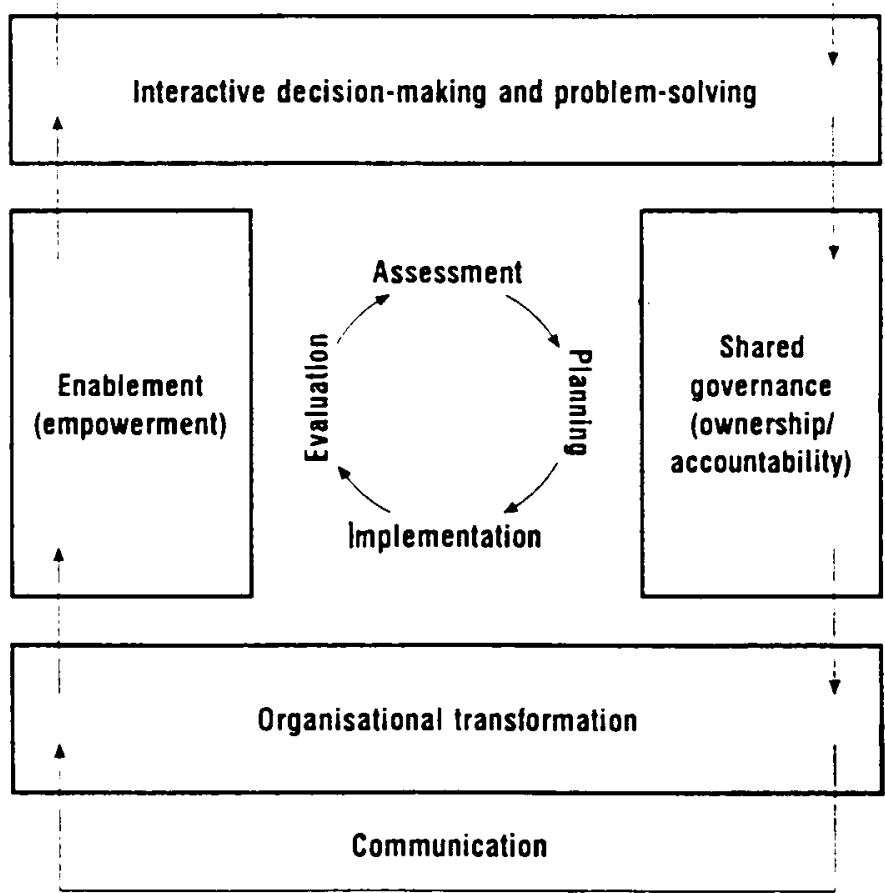

Figure 1 The process of participative management

of the role-players concerned with a particular decision or problem. Participation is depicted as a continuum from minimal to maximal participation (refer to Figure 2), with evolution of the most appropriate decision-making strategy in relation to the nature of the decision to be taken. This may be functional and operational/transactional, or visionary and strategic / transformational and is taken in terms of the needs, demands or expectations of the role-players affected by the decision (refer to Figure 3), and the level of professional maturity of both the manager and other role-players (refer to Figure 4 ).

\section{Continuum of interactive decision-making} and problem-solving

It is unrealistic to involve all role-players in every decision to be taken in the health care delivery system. Interactive decision-making and problem-solving therefore is depicted as a continuum from minimal to maximal participation (see Figure 2) utilising various decision-making strategies such as consultation, consensus, negotiation or democratic decision-making, depending on the type or nature of decision to be taken and in accordance with the level of interactive decision-making required. This process is dynamic and is influenced also by the needs. desires and expectations of the various role-players as well as their abilities such as knowledge, skills, values, reliability and informed commitment.

\section{The role-players in interactive decision-making and problem-solving}

Different role-players or actors are involved in the delivery of health care, namely the health care providers, health care consumers and the financiers, either state/private funders or insurers (see Figure 3). The health care providers consist of the members of the professional health team such as medical practitioners, nurses, pharmacists, physiotherapists, occupational therapists, etc. The health care provider also may be represented by a recognised employee organisation (eg. an association or union).

Management is divided into various levels of management, eg. top management, departmental and unit-managers. No health care service can he rendered without the necessary support services as for example, administration. technological services, household and food services. The health care consumer is the patient, his family and the community. The person responsible for payment also has a need to be included in the decision-making process. The challenge is to decide who should be included in the decision-making process and when to include them. This problem could be addressed by analysing the different levels of interactive decision-making in the health care delivery system.

Levels of interactive decision-making and problem-solving in the health care delivery system

There are different levels of interactive decision-making and problem-solving in the health care delivery system which will have a significant influence on the participatory process. Levels at the transactional level . where the so called grass roots work is performed by the various health care providers - may move lowards the transformational level 
Decision-making continuum

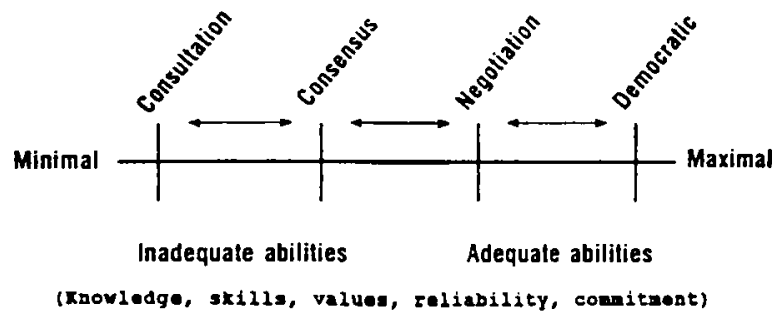

Enablement continuum

Figure 2 Continuum of interactive decision-making and level of enablement in a health care delivery system

which is more visionary or strategic (see Figure 4). At the grassroots level where the specific job is performed or professional health care is practised, independent (process-related) decision-making and problem-solving takes place, based on the needs, desires and expectations of the health care consumer, as well as on the ability of the health care provider. This takes place within the applicable professional-ethical framework, as well as within the organisational framework/culture which encompasses the philosophy, policies and standards accepted. In participative management, joint decision-making and problem-solving also is required to be related to various organisational outcomes, namely the quality of health care rendered and cost-effectiveness.

The span of decision-making and problem-solving increases at the unit and departmental levels, requiring inter-dependent decision-making and problem-solving between the various role-players, based on the nature of decisions and the enablement level of decision-makers. The most applicable decisionmaking strategy is employed at this level.

Visionary and strategic decision-making take place at the organisational level, resulting in organisational transformation (re-positioning and re-engineering) to meet the needs, desires and expectations of the customer - in health care delivery this is the patient, his family and the community. This requires autonomous decision-making and problem-solving based on the vision of the health care organisation. The selection of the most applicable decision-making strategy is based too, on the needs, desires and expectations of the various role-players in transformational decision-making.

\section{Decision-making strategies}

Different strategies may be employed for decision-making in relation to the affected organisational level, the type of decision or problem (e.g. functional/transactional or visionary/transformational, as illustrated in Figures 2 and 4 ), and the intensity of involvement required from the role-players. Application of the different strategies are determined in relation to the continuum of role-player involvement.

\section{Consultation}

Consultation implies that the manager earnestly seeks ideas, advice and help from employees that concern a certain subject or issue prior to decision-making. The manager approaches the subject with an open mind. attempting to solicit criticism and suggestions with sincerity in relation to the contemplated change or problem that needs to be solved (Haimann, 1993:301; 309). Brain-storming. as a form of free association generated during restricted group interaction, may be used to stimulate group members in order to develop a great number of new ideas uncritically within a specific time period. The purpose of breaking through individuals' habitual thought patterns is to facilitate creativity - the production of new and unusual ideas about a subject or problem (Gillies, 1989:451).

Another method of consultation is group decision-making which is a form of pooled expertise. Here the manager defines the problem, sets the limits, but allows the employees/ participants to develop the altematives and make their respective choice (Haimann, 1993:309).
Consensus decision-making

Consensus decision-making refers to unanimous or adequate agreement by group members. The implication is that an adequate debate should be held on the subject with regard to the advantages, disadvantages and impact-analysis of the options.

One of the disadvantages of reaching unanimous agreement is the time factor owing to possible serious prolixity in the meeting or deliberations. The price of unanimity is often a compromised solution and reduced to a lower common denominator that may not be as ingenious and bold as it could have been

The particular situation and the magnitude of the problem will determine whether or not unanimity is worth this price (Haimann, 1993:212). When utilising this decision-making strategy the manager strives towards unity in the organisation.

\section{Negotiation}

Negotiation utilises collective bargaining based on identified bargaining power. The intention of this strategy is that a mutual agreement be reached between the two parties involved and is usually employed for salary determination (Schulz \& Johnson, 1990:66).

Negotiation is therefore a process whereby two or more parties need to arrive at a mutually acceptable agreement in respect of conflict or a dispute. Good faith negotiation is important and information should not be distorted. The labour relations legislation in the public service legalises the obligation to negotiate matters of mutual interest, especially regarding conditions of employment.

\section{Democratic decision-making}

In democratic decision-making a formal voting procedure is employed, accentuating the differences among group members. If an individual is a member of the losing minority,

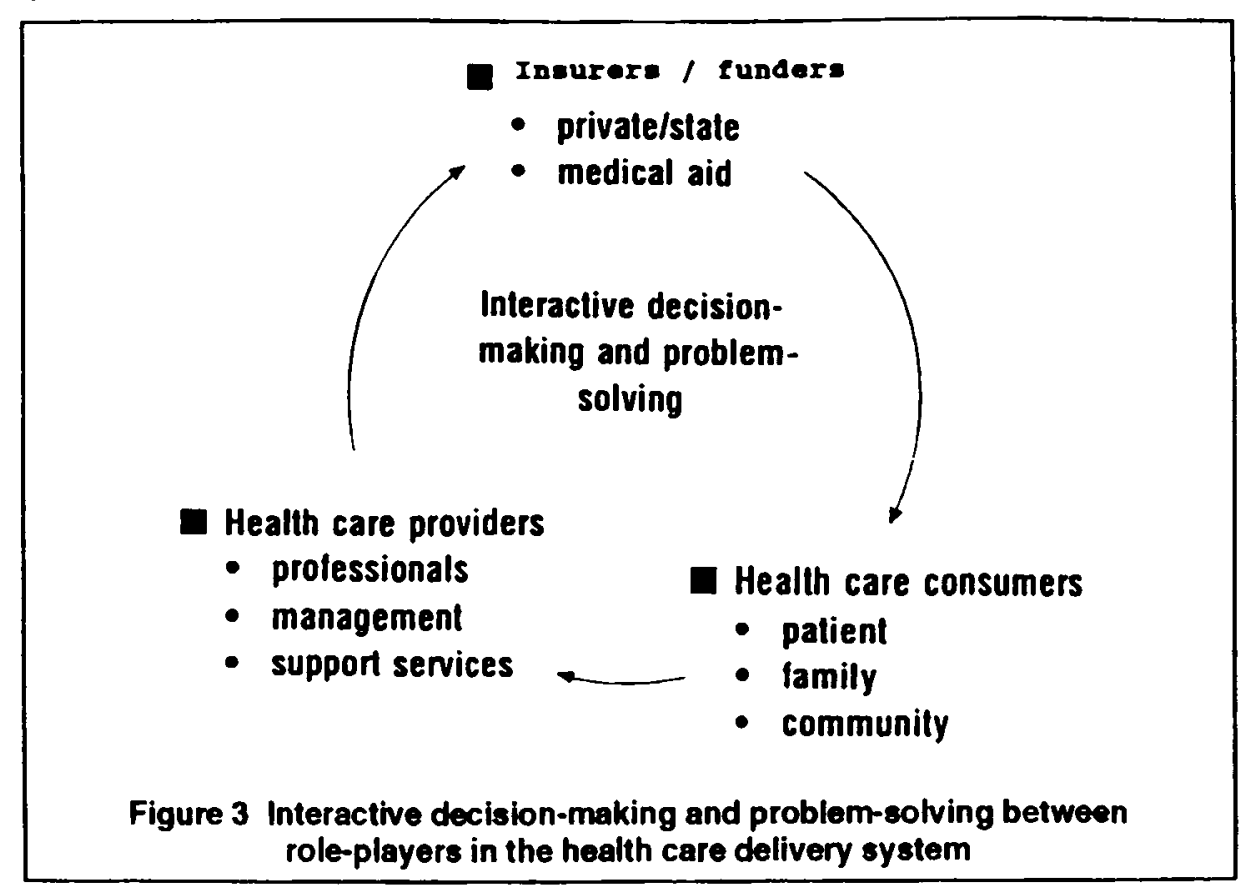




\section{functional/operational transactional}

visionary/strategic

transformational

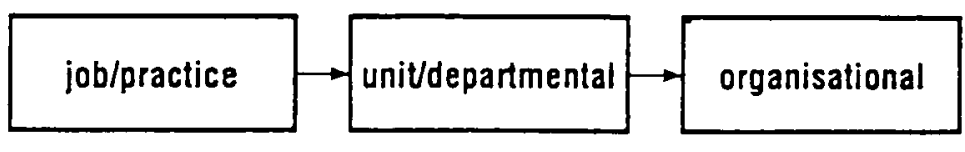

$\Delta$

Figure 4 Levels of interactive decision-making and problem-solving in a heaith care delivery system

he/she will not comply with the majority decision in any enthusiastic way, thus jeopardizing shared ownership of the outcome once the decision is implemented (Haimann, 1993:212).

Democratic decision-making in health care management is usually proceeded by a brain-storming session. A content analysis of ideas and suggestions is grouped and classified in a logical manner. Formal voting by the participants takes place.

In some management situations a democratic decision-making strategy can be utilised by means of the nominal group technique whereby group members identify and prioritise ideas, suggestions, goals, alternative problem-solving solutions and more, under non-threatening conditions. Low-status group members are often reluctant to reveal openly their opinions concerning some controversial issue for fear of being ridiculed by high-status group members. To minimise the inhibitory effect of status differences on group decision-making, non-interactive and interactive deliberations by group members could be combined when using the nominal group technique.

Group members are given the opportunity to generate ideas, goals, etc. and then asked to share ideas with the rest of the group in a round-robin fashion. Once clarification and clustering/grouping of different ideas has been done, voting takes place. Quantification of ideas/goals/solutions is carried out and priorities determined in accordance with a democratic voting system (Gillies, 1989:452).

Fishbowling is another democratic decision-making strategy, designed to improve the quality of decisions. A fair and full hearing for each member's opinions and suggestions is ensured. This method provides for reasoned and orderly group decision-making by eliminating distracting talk and irrelevant discussion.

Decision-makers sit in a circle around a central empty chair.

The person taking the central chair can introduce any subject and explain his viewpoint on the matter without interruption.
After having completed his/her presentation, the person awaits to answer questions posed by other group members until the subject debate is saturated. After all group members with ideas have taken their turn in the central chair, any group member subsequently may occupy the central chair for the purpose of recommending one of the proposed ideas. A majority vote in support of the recommendation of any member who has occupied the central chair will close the session (Gillies, 1989:453).

\section{Proactive and reactive decision-making}

Both these strategies are utilised in interactive decision-making and problem-solving. Predictable issues are proactively addressed whilst a reactive approach is employed to deal with existing problems or a crisis.

Principles and assumptions of interactive decision-making and problem-solving

Interactive decision-making and problem-solving is based on the following principles and assumptions:

- internal and external environmental factors determine the nature of decision to be taken and the degree of intensity of the required involvement of role-players;

- internal and external environmental factors are related to the needs, desires and expectations of the role-players involved in participative management, namely the health care providers, consumers and financier;

- different types of decisions (e.g functional/ transactional or visionary/ transformational) require involvement of participants at different levels in a health care organisation:

- the role-players' level of enablement (empowerment) is related to their interactive decision-making and problem-solving abilities (knowledge, skills, values, reliability and informed commitment);

- interactive decision-making and problem-solving is divided into three main areas of involvement, namely, professional practice-related issues, quality of work life, and managerial output matters;

- the process of interactive decision-making and problem-solving expands and intensifies as enablement and grow th of the different role-players take place, as well as organisational transformation.

\section{b) Shared governance (ownership and accountability)}

Shared governance (ownership and accountability) is the second element of participative management, and refers to the establishment of a trust relationship amongst the role-players through direct, interactive involvement in decision-making and problem-solving, with the subsequent shared responsibility and accountability for the consequences of the decisions, whether successful or not. Here, devolution of authority and subsequent management autonomy to the lowest possible level in the organisation is a prerequisite.

The individual's job or professional practice process related activities are linked to the organisational outcome activities, being quality and cost: efficiency or effectiveness.

\section{Principles and assumptions}

Shared governance is reflected in the following principles and assumptions:

- a critical organisational success factor is shared values (congruency between individual and organisational values) with the implication that most of the important quality and practice-related decisions are made without the presence and control of the management;

- interactive decision-making and problem-solving is present in functional/ transactional and transformational/ visionary (strategic) planning:

- autonomy is granted for both process and outcome related decision-making and problem-solving. in accordance with the level of role-players' enablement/ empowerment reliability and informed commitment;

- progressive, decentralised, shared governance and participative management is demonstrated in relation to the degree of personal, professional and organisational enablement/empowerment;

- accountability (process and outcome) in relation to interactive decision-making and problem-solving is accepted at the lowest possible organisational level;

- productuvity is increased, and quality of work life as well as general organisational outputs are improved through shared governance. 


\section{c) Organisational transformation}

Participative management requires a radical organisational paradigm shift. Organisational transformation implies dynamic personal, professional and organisational change and renewal to meet the needs, desires and expectations in terms of the internal and external environments and to accommodate the principles of participative management. This therefore implies a dynamic re-engineering or re-alignment of the health care service: vision, mission, philosophy, policies and structures.

\section{Principles and assumptions}

Organisational transformation is characterised by the following principles and assumptions:

- a qualitative organisational analyses (structure and process of interactive decision-making and problem-solving, for shared governance) is performed by the role-players;

- consensus determines the transformational needs of the organisation, reaffirms the organisational values, philosophies, and appropriate structural change in order to address the requirements of participative management, and supports the values and a strategy for implementation;

- dynamic structural organisational changes are made which are based on the qualitative transformational analysis;

- the organisation is mobilised to transform its organisational patterns;

- personal, professional and organisational transformation is demonstrated in the health care organisation;

- leaders and managers act as change / transformational agents;

- creativity and risk taking are displayed by the role-players:

- supervision is replaced with an climate of self-management

- progress, in terms of transformational structures and patterns, is demonstrated in the implementation of participative management in accordance with the level of personal, professional and organisational development and enablement of various role-players.

\section{d) Enablement ("empowerment")}

Enablement ("empowerment") is a deliberate, planned social process of recognising, promoting and enhancing people's abilities to meet their needs, desires and expectations related to participative management in a health care organisation. This includes the provision for localised authorisation in terms of interactive decision-making and problem-solving.

\section{Principles and assumptions}

Enablement / empowerment for participative management is based on the following principles and assumptions:

- mutual respect amongst the health care role-players is a prerequisite for the enablement process;

- a move towards participative management honours the values of integrity, uniqueness, potential and autonomy with responsibility;

- leaders and facilitators are employed for the purpose of supporting, counselling, educating, acting as resource consultants, resource mobilisers, advocates and enablers;

- transformational leadership is the key to enablement / empowerment

- personal, professional and organisational enablement / empowerment focuses on decision-making and problem-solving abilities, organisational restructuring (localised authorisation), the principles of planned change and group dynamics;

- total involvement in the implementation of change facilitates enablement / empowerment;

- deliberate disempowerment in terms of traditional practices and styles is required;

- enablement / empowerment fosters mutual personal and professional growth of both the person being empowered and person empowering others;

progressive empowerment is displayed:- as abilities increase, localised authorisation and accountability (shared governance) intensifies in terms of both process and outcome.

\section{e) Dynamic communication}

Participative management requires dynamic communication amongst all role-players in the health care delivery system, both inside the organisation and in the external environment. Organisational transformation also requires communication transformation which implies the establishment of new communication networks to foster participative management. The role-players need access to both the available information and the decision-making processes. Appropriate and dynamic feedback networks need to be established between the decisionmakers and the management. Effective communication is an obligation - it is the lubrication for effective participative management. The flow of information needs to be re-engineered, taking into account the various target groups in the health care organisation, which include the employee organisations' representatives and union shop-stewards or representatives.
Principles and assumptions

The communication network is dynamic and makes provision for the following:

- transparency and clarification of transformational demands, strategies, etc.;

- dynamic communication loops and feedback strategies between the various role-players and unit/departmental structures;

- trust between role-players is earned, based on effective communication and follow-through strategies;

- clear and realistic goal-setting in terms of the preparation and implementation of participative management;

- communication should service the organisational policy.

\section{GUIDELINES FOR PARTICIPATIVE MANAGEMENT}

Guidelines for participative management are divided into three phases, namely a preparation, implementation/formalisation and evaluation phase.

\section{Preparation phase}

Starting the project on the right foot is critical to success. In this phase setting the stage for participative management is important and this requires personal, professional and organisational transformation. The scientific method of assessment, planning, implementation and evaluation is recommended.

\section{a) Qualitative analysis}

A qualitative analysis of the health care delivery organisation is required. An analysis of the needs, desires and expectations of the internal and external environment is done incorporating the organisational structure (authorisation/accountability levels) and the abilities (knowledge, skills and values), as well as the level of informed commitment by the role-players.

Existing decision-making structures are analysed - the type of decisions taken, by whom, level of involvement, decision-making strategies utilised, etc. A qualitative analysis / assessment regarding all four elements of participative management - including communication - is performed.

It could be meaningful to determine the existing level of job-satisfaction or quality work life experienced by employees, as baseline to compare the degree of success accomplished with the implementation of participative management.

\section{b) Planning}

Planning should focus on the process of 
participative management, (interactive decision-making and problem-solving, shared governance, organisational transformation and enablement, including a dynamic communication network), as well as on the principles of change management. In planning the creation of new structures to facilitate participative management, the principles of interactive decision-making need to be utilised to foster ownership for the personal, professional and organisational transformation that is going to take place.

The next step would be to re-educate formally the role-players in preparation for participative and change management. The focus would be on interactive decision-making, problem-solving, group dynamics and the principles of planned change as the main aspects.

Monitoring the readiness for change is also important. A formal plan needs to be developed in which the project goals are defined, the project leaders and the required resources identified and mobilised. Responsibilities during the preparation and implementation phases of the projects need to be assigned.

An essential element is to obtain informed commitment from the role-players. A communication plan and strategy need to be prepared through the establishment of the necessary work groups (task force) and the development of a comprehensive, ongoing communication plan. Project planning is done in terms of all four participative management actions:- interactive decision-making and problem-solving, shared governance, organisational transformation and enablement, encompassing the principles of change management.

The preparation phase is characterised by setting the climate for change and transformation as well as creating a sense of security amongst the different role-players.

The establishment of at least the following committees is recommended, namely a briefing committee, quality circles and financial audit committees.

The briefing committees are area/unit communication committees and they should be responsible for communication within the organisation. The most acceptable communication strategies, based on the various role-players' needs, desires and expectations would be used. A quality circle is a form of peer group review which is confidential and focused on practice rather than practitioners. Quality circles are groups of people, numbering between six to twelve. from the same area or unit, who meet regularly (eg. monthly) to discuss the quality of work/practice and to solve problems they experience in the work situation in meeting the desired goals. Quality circles embody the principle of participative management to its fullest. They are based on the assumption that an organisation's workers are closest to the problem and indeed may be part of the problem and that therefore they are best equipped to remedy it, thereby increasing their potential and quality of service rendered. The financial audit committee should be responsible for cost control in the area or unit therefore accepting financial accountability for a particular area or practice.

During the preparation phase these committees function on a more informal basis focusing on empowering themselves regarding group dynamics, problem-solving and the specialised knowledge required in terms of communication, quality and financial control.

\section{Implementation or formalisation phase}

During the implementation/formalisation phase, the necessary support systems need to be employed, such as facilitators, project leaders, consultants, etc. Emphasis should be placed on motivational strategies. Close monitoring of problems, lessons, reasons underlying successes and failures, will enhance the transformational process. Depending on the size of the organisation. pilot studies could be beneficial, utilising the principle of gradual change based on voluntary participation. An ongoing empowerment programme is necessary, progressing as personal, professional and organisational enablement takes place.

During this phase the committees could be formalised, displaying progressed empowerment - knowledge, skills, informed commitment - as well as progressed shared governance - taking responsibility, ownership/ accountability, not only for the job/practice related or transactional decision-making and problem-solving, but also for the total area/unit's outcomes. Localised authorisation at unit level is formalised in terms of the planning, implementation and evaluation of the goals, ultimately resulting in improved organisational outputs.

\section{Evaluation}

Formal evaluation of goal achievements is done in accordance with the planned dates and intervals, involving all the role-players. Contributing factors, whether beneficial or not, need to be identified and analysed. The overall success of participative management needs to be evaluated in terms of organisational output: the quality of health care service, financial efficiency and the quality of work life experienced by the employees.

\section{CONCLUSION AND RECOMMENDATIONS}

Health care services not only affect the well being of society but also consume a significant part of any country's wealth and employ a large number of people. The performance of services can not expect to escape regular attention - especially from the health care consumer and the financier. Quality patient care is provided by a complex blend of multidisciplinary technological and human resources. All activities must operate in a rapidly-changing environment that imposes a broad range of pressures on the provider of services, as well as the user. In order to serve the public adequately, quality health care management should promote active collaboration between the staff and the management. Working together facilitates problem-solving and promotes accountability.

The implementation of participative management in a health care organisation poses a tremendous challenge for the health service managers. Change is never effected without difficulties, but the potential for personal, professional and organisational growth is unlimited and very worthwhile. In this article a model for participative management has been proposed, consisting of interactive decision-making and problem-solving, dynamic organisational transformation, shared governance (ownership and accountability), enablement (empowerment) and dynamic communication.

Change is a journey requiring a specific mode of transport. Even the most meticulously planned journey can be subject to unpredictable delays, detours and diversions. But a plan for participative management is required - based on a qualitative analysis of the health care delivery system's needs, desires and expectations to accommodate the most suitable participative management strategy for the organisation. This will, however, require abundant wisdom.

It is recommended that this proposed model for participative management be refined by means of a literature control, interactive dialogue with experts and a model case description of participative management to ensure trustworthiness of this research.

\section{REFERENCES}

GIBSON, CH (1991): A concept analysit of empowerment. Journal of Advanced Nursing. 16 (3), 354-361

GILLLES, DA (1989): Nursing management. A systems approach. Philadelphia: WB Saunders.

HAIMANN, T (1993): Supervisory maragement for health care organizations; fifth edition. Dubuque: Wm. C. Brown Publishers.

SCHULZ, R \& JOHNSON, AC (1990): Management of hospitals and health services. Strategic issues and performsnce. St. Louns: CV Mosby

STANDER. JW (1992): Deelnemende bestuur in 'n verploegdiens. Aucklandpark: Randse Afrikanse Universitent (M.Cur-vertandeling)

SWANSBURG, RC (1993): Imroductory management and leaderahip for clinical nures. A lext-workbook. Boston: Joncs and Bartiet Publishers.

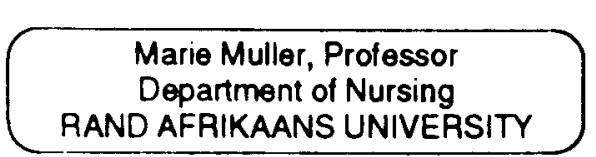

